\title{
BASIC TEACHING SKILL OF BALINEES COUNSELOR AT BANJAR DISTRIC BULELENG REGENCY
}

\author{
Ni Luh Degeng Ratna Dewi' ${ }^{1}$ Ida Bagus Putrayasa ${ }^{2}$, I Ketut Paramartha ${ }^{3}$ \\ ${ }^{123}$ Indonesian Education Study Program, Postgraduate Program, Universitas Pendidikan Ganesha, Indonesia
}

\section{Keywords:}

basic skill of learning; baliness counselor

Correspondance address:

ABSTRACT

Abstract: This researche aimed at (1) describing basic skill of Balinees counselor at Banjar distric, Buleleng regency, (2) The problem in implementing basic skill of Balinees counselor, (3) The factor causing the problem in implementing basic skill of Baliness councelor, (4) The solution describing based on the real factors in implementing basic skill of Balinees coubselor in learning procces. The design of this research is descriptive qualitative. The sample were 12 people of Balinees counselor from Buleleng regency. Data collection technique used interviewing and observation. The analysis of data was started from data reduction, proccessing/displaying, and given solution. The results of this research was most of the Balinees counselor did not apply basic skill of teaching to teach Balinees language efficiently and maximally. It was proven with (1) the diffuculty of the Balinees counselor in mastering the content of learning as a result they were difficult to teach the content of Balinees language to the learner in learning procces. (2) Lack of interest of the learning to deeply learn about Baliness language. (3) Lack of facilities in supporting Baliness counselor in teaching as a result they got a difficulty in sharing knowledge to the learner. The solution given by the researcher were staurted from variating technique of teaching of Baliness to learner in learning procces, being discipline in mastering class or atmosphere of the class during learning procces. In addition, the researcher provided correlative media in implementing basic skill of Baliness counselor. In summary, the result of this research done was not effective.

E-mail: ratnadegeng@gmail.com (Ni Luh Degeng Ratna Dewi)

\section{Introduction}

The decline in language use on the island of Bali is increasingly visible. It can be seen from the language ability of the children is still lacking in using the language of Bali. Not only among the children who experienced a decline in using the language of Bali, but among teens also experienced a decline in using the language of Bali. It's like mixing up the use of Balinese with other languages when communicating. Various efforts and strategies have been undertaken to preserve Balinese language, Aksara and Balinesse literatures from the threat of extinction both in education through schooling, Balinese literary contests, Balinese language congresses and other programs promoting conservation aspects. This is supported by research Budiasa (2013) reported that the issues studied about Balinese language objects related to the choice of language in tourist destinations Kuta, Bali. Research like this is important to remember when the use of the language of Bali has begun to decline among adolescents.

With the existence of Bali language decline that existed among the people of Bali, the Bali instructor was appointed. Government efforts since 2016 by recruiting extension Bali language that is expected to change the order of Bali language among children for the better. The existence of 
recruitment of Bali language extension by Bali Provincial Culture Office 2016/2017 with various considerations. As well as taking into account the environment of Balinese society. If culture, language and literature get a more specific touch will have a better impact for the future.

The task of a counselor is to motivate and invite students and community learners in Bali to develop the use of Language, Aksara, and Balinesse Literature. The function of the Balinese counselor is to educate. And educate means that the Balinesse language instructor has function to give the information about all things that are related on language, Aksara, and Balinese Literature, as well as responsible to educate and develop Balinese language as a valuable heritage.

To perform the duties and functions of the Balinesse language counselorcannot be separated from the eight basic skills of teaching. The eight basic teaching skills that are very influential on the learning process in the classroom, namely: 1). Giving Strengthening Skills, 2). Questioning Skills, 3). Skills using Variation, 4). Explaining Skills, 5). Opening Skills and Closing lessons, 6). Teaching Skills for Small Groups and Individuals, 7). Classroom Management Skills, and 8). Skills Guiding small group discussions. The Balinese language counselor must master the eight basic skills of teaching, so that learning can be achieved maximally and the students more easily understand the material given (Hasibuan et al, 1991). The eight components of basic teaching skills are very important to be mastered by the Balinese language instructor, because without mastering the eight basic skills of teaching then a Balinese language counselor will not be able to apply the learning maximally.

The Balinese counselor must master the basic skills of teaching in teaching and learning process, so when the counseling takes place, there will be multi-way communication and the purpose of counseling can be achieved well. Therefore, before counseling, the Balinese counselor should really master the basic skills of teaching even though the application has not been maximized, but the extension objectives can be achieved. Therefore, the researcher decides the problem to be packaged into scientific research in the form of a thesis entitled "The Basic Teaching Skills of The Balinese Language Counselor in Banjar District Buleleng Regency".

\section{Research Methods}

This research uses qualitative descriptive research. This qualitative descriptive research is chosen by the researcher to describe the real situation about the basic skills of counselor in teaching the Balinese language.

The location of this research is the Balinese language counsellor at Banjar district Buleleng regency. The types of data collected in this study are the basic skills of teaching the Bali Language Counselor, the constraints found in basic teaching skills, the factors that affect the constraints in applying basic teaching skills, and proposed solutions to the basic skills skill component of teaching. The data source in the research is the primary data source. Sources of data in this study are students of Elementary School and The Balinese Language Counselor in Banjar District Buleleng Regency which can be through interviews and observation of teaching and learning process in class.

Data collection method in this research is by using observation and interview method. Observation method used is non participatory observation. And in the method of interviews conducted is unstructured interviews so that respondents can answer freely in accordance with the thoughts and contents of his heart, but also respondents can be straightforwardly put forward all things that want to said.

The instruments in the study are in the form of observation guidelines and interview guidelines. Observation guidelines are used by researchers to find data on basic skills of the Balinese counselor. And interview guides are used by researchers to find data on the basic skills component of teaching when applied by obstetric Balinese counselors, factors that cause obstacles in applying the basic skills of Balinese language counselors, and proposed solutions in the basic skills component teaching the Bali language counselor.

Techniques of data analysis of this study consists of 3 stages, namely: 1) data reduction, 2) Presentation of data, 3) Data inference. 


\section{Data reduction}

In reducing the data, the Bali language counselor identifies data related to the problem and chooses data on the basic skills of teaching Balinese counselor by using an observation format that contains the observation guidance of the Balinese language counselors, the teaching skills constrained when applied to the Balinese language counselor, the factors that causes difficulties in applying the basic skills of teaching the Balinesse language counselors, and the proposed application of proposed solutions in the basic skills component of teaching Balinese language counselors also uses interview format. Interview format containing interview guide.

\section{Data Presentation}

Reduced data will be presented description data which will be described in detail and clear. After the data passes through the reduction, the problems studied in the study, such as about the basic skills of teaching Balinese language counselors, the components of teaching skills that are constrained when applied to the Bali language counselor, the factors that cause obstacles in applying the basic skills of asking the Balinese language counselor, solutions that can be proposed in the basic skills component of teaching Balinese language counselors.

\section{Data Conclusion}

The last step of this research data processing method is to draw conclusions. Interesting and conclusions are attempts to describe the results obtained from data processing, on the basic skills of teaching the Balinese language counselor, the components of teaching skills that are constrained when applied by the Balinese language counselor, the factors that cause obstacles in applying the basic skills of teaching the Balinese language counselors, proposed application of proposed solutions in the basic skills component of teaching Balinese language counselors.

\section{Result and Discussion}

Bali language counselors in SD Negeri 1 Banyuatis Still lacking in applying the basic skills of teaching namely:

1. When using questioning skills especially on the basic skill questioning component the counselor has applied the seven components that exist in the basic ask skill. However, the guiding component of the guidance does not extend as the lesson takes place and the counselor does not apply advanced questioning skills. In addition, the counselor has also avoided the habits that should be avoided in asking questions.

2. Strengthening skills, the counselors do not all apply the types of reinforcement that exist in strengthening skills. The counselors only use mimic and body movement only while the motion of approaching, touch, fun activities, the provision of symbols or objects he has never applied in the classroom. The counselors do not vary widely in the types of reinforcing skills. Counselors sometimes only provide reinforcement in the form of verbal only, sometimes on the contrary that the extension only use non verbal reinforcement alone. Should the time of the course counselor should vary the existing strengthening, not only strengthening varbals are used but non-verbal reinforcement is also used when the learning takes place so that will add enthusiastic students.

3. In skills using variation, counselors when applying basic teaching skills are good when applying them. But he only applies one component to the skill of using variations, such as variations in teaching styles. The variation in the teaching style applied by the counselor has varied, such as variation of voice, change in teacher position, silence, contact seeing, etc. In applying the basic skills component of teaching that is the skill of using variation, the Balinese language counselor when applying it using only one component that exists in the skill of using variations. Supposedly when applying skill using variation not only one of its components is applied but all existing components are also applied. 
4. In the skill of explaining, the counselor is good either in planning explanations or in presenting the material. This is because before the counselor gives explanation in advance, the counselorchoose the right materials according to the ability of students and the counselors already understand about the characteristics of learners. So when presenting the counselor materials just use the source in the book only but also looking at other sources and when explaining the counselorsgive emphasis so that students more easily capture the core of the explained problem.

5. Furthermore on the skills of managing the class, counselors have not maximized in applying the skills to manage the class, for example on the skills component that is preventive. One component that is preventive is to provide reinforcement. In this component, the counselor only applies his ability by rebuking with harsh expression and body movement while other ways such as focusing, focusing on responsiveness, sharing attention, giving clear clues he has never applied. In addition, most counselors also do not understand the purpose of classroom management. So that learning does not take place conducively. The implementation of the skills of managing classes conducted by the Balinese language counselor is not maximal because it does not pay attention to the purpose of the classroom management so that will be achieved a conducive learning.

\section{Observation in Dencarik Village}

1. In skills using variation, counselors when applying basic teaching skills are good when applying them. But he only applies one component to the skill of using variations, such as variations in teaching styles. Variations in teaching styles applied by counselors vary as variations of sound, changes in teacher position, silence, contact perspective, and so on. In applying the basic skills component of teaching that is the skill of using variation, the Balinese language counselor when applying it only uses one of the components that exist in the skill of using variation. Supposedly when applying skill using variation not only one of its components is applied but all existing components are also applied.

2. Skills open and close lessons, counselors when opening lessons there is no apperception activities. He immediately opened the lesson by giving the material. In addition to his opening skills he is maximally in applying closing skills lessons. For example when the lesson is over, he immediately test the students one by one with questions that relate to the material that has been explained by the counselorbefore and concluded the material already given by the counselor. Skills open and close the lessons applied by the counselor of Balinese language has not been maximal it can be seen on the skills to open the lesson there is no apperception. Supposedly before the instructor starts the instructor first apersepsi. Because the purpose of this apperception is to introduce the subject of the lesson by connecting it to the knowledge already known to the learner.

\section{Observation in Banjar Village}

1. In the skill of using variations, the Banjar Village Counselor only applies one component to the skill of using variations, such as variations in teaching styles. Variations in teaching styles applied by Banjar village counselors have varied, such as variation of voice, change in teacher position, silence, contact seeing, and so on. In addition to the variation of teaching styles, variations in the use of teaching aids are also used by Banjar village counselors. For example the use of LCD when learning reading Balinese script. With the help of LCD tool then the students do not feel bored and not behind in following the learning in the classroom. In applying the basic skills skill component of teaching that is the skill of using variation, Balinese language counselor when applying it using only one component exist in skill using variation. Supposedly when applying skills using variations not only one component is applied but all the components are also applied.

2. In the skill of opening and closing lessons, Counselor of Balinese language at Banjar village BanjarDistrict when opening lesson there is no apperception activity. He immediately opened the lesson by giving the material. In addition to the opening skills he is also not maximized in applying closing skills lessons. For example when the lesson is over, he immediately closed it with parama santi. The skill of opening and closing the lessons applied by the Balinese languagecounselor has not been maximal it can be seen in the skill of opening the lesson there is no apperception and on 
the skill of closing is also no inference. Supposedly before the lesson starts the counselor first do apperception. Because the purpose of this apperception is to introduce the subject of the lesson by connecting it to the knowledge already known to the learner.

\section{Observation in Cempaga Village}

1. In the questioning skill, the Cempaga Village counselor only uses basic questions only and does not ask the follow-up questions to the students. For example, the Balinese languagecounselor is limited to asking about examples of essays only, not asking more broadly about writing. Should the time of the course progressed the counselor should vary the existing strengthening, not only the varbal reinforcement is used but non-verbal reinforcement is also used when the learning takes place so that it will add to the student's enthusiasm.

2. Strengthening skills. In applying strengthening skills, not all counselors apply the types of reinforcement that exists in strengthening skills. He only uses mimic and body movements that are part of non-verbal reinforcement, verbal reinforcement is also applied by the counslor of Cempaga Village for example, give praise to students when the answer is true with the form of words or sentences. In the application of the basic skills component of teaching that is the skill of giving emphasis of the counselor is less than optimal when applying it. Because counselors sometimes only provide reinforcement in the form of verbal only, sometimes on the contrary that the counselor only use non verbal reinforcement alone. Should the time of the course progressed the counselor should vary the existing strengthening, not only the varbal reinforcement is used but non-verbal reinforcement is also used when the learning takes place so that it will add to the student's enthusiasm.

\section{Observation in Temukus Village}

1. The counselor in Temukus Village only apply six basic skills component of teaching while others are small group skill and individual and small group guiding skill never applied during the learning process. The six components of basic teaching skills applied by Temukus Village counselors are good, apart from understanding each of the components in basic teaching skills, he also avoids the habits that should be avoided in the skill. For example, on the questioning skills of the Balineselanguagecounselor at Temukus village never repeats the question itself or answers the questions themselves, repeats the students' answers, asks questions that invite simultaneous answers, multiple questions, and determines which students will answer questions, etc. At the time of the course, the counselor has applied questioning skills. In the application of coounselors do not pay attention to the habits to be avoided in asking, should the counselor other than understand the function of the question must also consider the habits to be avoided.

2. In the skill to explain the counselors already understand the meaning and purpose of the explanatory skills such as when the learning took place,counselor assist students in understanding the various concepts of the material given. In addition, the counselor also leads students to answer questions.Not only that the counselor also understand the principles of use of skills explain.

From the above data can be concluded that the Balinese language counselor in applying the basic skills of teaching has been maximized. But there is still something to be repaired by counselors so that when applying it in accordance with the expectations of counselors. And the constraints do not happen again.

The constraints that experienced by the Balinese Language Counselor at Banjar District when applying the basic skills component of teaching

1. The Balinese Language Counselor

The constraints faced by counselors are: first, the counselor difficulties in determining the method and difficulty determining the delivery of learning materials are fun. This makes the learner less motivated and inactive in following the lesson; secondly, the counselor does not fully understand the components in the eight basic teaching skills. For example, when applying the skill 
of asking,counselors are still confused how to put the basic questioning skills and ask further when the learning takes place. Should in providing learning should be effective, efficient and fun is the learning that occurs when the existence of multi-way interaction means not only active teachers but also learners participate actively

\section{Learners}

The constraints faced by counselors are: learners are less like learning the Balineselanguage. For learners Balinese language lessons are very difficult to understand either from reading or writing. Therefore learners have difficulty level in learning Balinese language. The counselor should have a good lesson strategy so that students can follow the lesson with fun.

3. Learning facilities

The constraints faced by extensionists are: not optimizing the learning tools that exist in the school. That's because schools do not provide learning tools that support the teaching and learning process. Schools should provide a complete learning tool so that learning can take place properly.

\section{The Factors that influence in applying the basic skills of teaching the Balinese languagecounselor in Banjar District Buleleng Regency.}

Factors that influence in applying the basic skills of teaching Balinese language counselor in Banjar District Buleleng Regency is generally influenced by three factors, namely (1) Balinese language Educator Factor, (2) Student Factor , (3) Learning Facility Factor. These three factors will be described as follows.

1. Educator Factor (Counselor of Balinese Language)

First, the Balinese languagecounselor lacks reading references. The Balinese language counselor before giving lessons only prepares simple material only and counselors do not seek other references to support the lessons they will be given. So when the counselor gives lessons in the class, the counselor is still less in determining the method and delivery of the material; secondly, the lack of experience of counselors in implementing learning. The experiential time of the counselor is one and a half years. The Balinese language counselor in applying learning in the classroom only has one year time, and six months is used to search the data of village organization. Thus the Balinese language counselors have only minimal or less extensive experience.

2. Learners Factor

Learners feel bored following the lessons of Balinese language. When the learning is done by counselors, there are learners who understand the explanation of counselor there are also who do not understand. From the number of 25 students only 2 to 3 students are able to understand the learning. The rest of them are still in doubt and some do not understand at all. So the Balinese language counselors are more focused and give more time to the students who are still lacking in understanding the lessons of the Balinese language. Learners who already understand the lesson is only asked to learn alone and not accompanied by counselors. It makes learners become bored while following the lesson and learners to dislike the lessons of Balinese language either students who have not been able and already able to understand the lesson. Of the differences in characters that greatly influence the counselor in applying the basic skills of teaching and make learners feel bored to follow the lessons of Balinese language.

3. Learning Facility Factor

Schools do not have the cost to purchase the means to support learning. Schools in rural areas, and schools often exposed to floods and landslides have not been able to buy tools to support learning such as LCD appliances, textbooks, markers, erasers, blackboards and so forth. Because the school is still thinking about the state of a comfortable school so as not to be hit by floods and landslides again. There is also a school that is far from disaster and the school has LCD, but the tool is broken and the school can not fix it. And unfortunately the school does not provide Student work sheets (LKS) books for its students, the students only use the package book when the learning takes place. Even students are not allowed to take home the package books used by 
the students. With the limited costs that exist in school, making counselors feel difficult in providing learning.

The Plan of Applying the solutions that can be proposed in the basic skills component of teaching the Balinese language Counselor in Banjar District

1. When using strengthening skills, not all counselors apply the types of reinforcement that exist within the reinforcement skills. Given these obstacles, researchers try to provide solutions to the Balinese language counselor is by asking the counselor of the Balinese language to varying use of the types of skills that exist in strengthening skills. Often we find students' answers that are partly true and partly wrong, for the counselor to use unfinished reinforcement, as the counselor said: "The first part of your answer is correct, but the reason you gave is not yet solid". The trainer then asks the other students to fix the answer that still needs to be fixed. That way, students will understand the quality of the answer so that the reinforcement can be really meaningful.

2. The Balinese language counselors are experiencing difficulties in opening and closing lessons. In the skill of opening lessons most of the Balinese language counselors do not perform apperception before the start of learning. And on closing skills, the counselor does not conduct feedback nor conclude the learning that has taken place. With these constraints, researchers try to provide a solution that is on the skills to open the lesson, the teacher should first open with apperception so that students have a shadow before learning is implemented. While the skills to close the lessons should be the Balinese language counselor before closing the lesson should make feedback on the lessons that have been going on. Given this feedback, counselors can know the success rate of learners in capturing and understanding the newly learned material.

3. Constraints faced by counselors mostly do not apply advanced questioning skills. And only limited use of basic questioning skills. In addition, the counselor also does not pay attention to the habits to be avoided when asking. Given these obstacles, researchers try to provide a plan of application of a workable solution. The solution is in addition to using basic ask skills, the counselor also applies advanced questioning skills. With the use of both skills to ask, the counselor will know the level of student ability to the material being discussed. The Balinese languagecounselor should also pay attention to the habits of asking questions. For example, ask a question that provokes a simultaneous answer. This habit is good to be applied to live the classroom.

4. In the skills of managing the class, most counselors have constraints on the components of classroom management skills and objectives of classroom management. With that constraint, researchers provide solutions to the Balinese language couselor when applying classroom management skills. The solution that is, the counselor should consider the situation and condition of the classroom that allows learners to develop their abilities to the maximum, such as inviting students to come out of the classroom and observe the school environment, eliminating various barriers and disciplinary violations that can obstruct the realization of learning and teaching interaction, stable classes so as to avoid disruption, serve and guide individual differences of learners, and organize all equipment and equipment for learners in the classroom. By understanding these objectives then learning can be created actively, and fun.

5. Next skills to hold variations. The constraints faced by the Balinese language counselors are largely not varied either in teaching style, interaction patterns, or aids. The solution given by the researcher is supposed the Balinese language counselor in addition to varying his teaching style must also vary the pattern of interaction and aids. For example, when the councelor learning Balinese language not only provide information only to learners, but also directly conduct question and answer or discussion of the material being discussed. In addition, counselors can also use tools that are appropriate with the material delivered. Given the variations in both teaching styles, vola interactions and aids, learning will be more conducive and the objectives of learning can be achieved. 


\section{Research Implications}

Research on the basic skills of teaching, especially on the application of components of basic teaching skills can be said that research should be done because the basic skills of teaching greatly affect the success of counselor in teaching. Basic teaching skill is the capital to be mastered by teachers or counselors. The Balinese language counselors before the learning or counseling takes place must precedence identify the character of the student so that it can determine the proper way of delivering the material.

Based on the case, the Balineselanguage counselors must have a pedagogical ability to make what is delivered in the classroom can be understood by the learners who can finally be given knowledge. The pedagogical skills are related to learning methods, classroom management techniques, media use, evaluation techniques to reflect the learning process.

In addition, the Balinese language counselors do not use variations, either from media, methods, and learning resources. Counselor of the Balinese language sometimes just simply compile the design of learning without using various variations that are used. For example, when teaching the material about the introduction of Balinese script, the method used is the method of lectures and question and answer. And at the next meeting the material taught about writing Balinese script, the method used is also the same method of lectures and question and answer. should the Balinese language counselors not only use the two methods that only the lecture and question and answer method at the time of learning can also use other methods so that in learning there are variations and students certainly not saturated because the method used does not generate student motivation.

Saturation and not the growth of students' motivation in following the lesson because the counselor is not maximal in applying basic teaching skills. As a counselor or teacher must master the basic skills of teaching in teaching and learning process, so that when counseling takes place, there will be multi-way communication and counselor purposes can be achieved well. Therefore, before counseling, the Balinese language counselors must really master the basic skills of teaching even though the application is not maximal, but the counselor objectives can be achieved.

Related to this research, it should be examined more deeply related to the basic skills of teachingcounselor in Balinese language because the counselor of Balinese language is not maximal in applying the basic skills of teaching either because it does not understand any concept of existing components in the basic skills of teaching or even apply basic teaching skills at the time learning takes place.

So, this research is implicated in applying the basic skills of teachingcounselors in Balinese language. If the Balinese language counselors can understand the concept of basic teaching skills, when implementing it does not find difficulties, and in other hand if the counselor is reluctant to understand the basic teaching skills concept and never apply it then when applying basic teaching skills, the counselor will find difficulties when applying the basic skills of teaching.

\section{Conclusion}

1. The basic skills of teaching the Balinese language counselor in Elementary School of the Banjar District Buleleng Regency is categorized as less. This can be seen when the counselor is lacking in the application of basic teaching skills: first, the counselor from Banyuatis Village is lacking in applying the skills of askingthe questions, strengthening skills, skills of using variation, and classroom management skills; secondly, from Dencarik Village still lacks in applying the skills of opening and closing lessons, and variation skills; thirdly, Banjar Village is still lacking in the skills of opening and closing lessons, and variation skills; fourth, from Cempaga Village is still lacking in applying strengthening skills and questioning skills; fifth, of Temukus Village is still lacking in applying the skills of small groups and individuals.

2. Constraints experienced by the Balinese language counselor in BanjarDistrict when applying the basic skills component of teaching, among others: Balineselanguage counselors using the method 
or delivery of material presented unpleasant. So as to make learners less motivated and inactive in following learning; learners do not like the Balinese language lessons, because Balinese lessons are very difficult to understand both in terms of reading and writing; and does not optimize the learning tools that exist in schools. That's because schools do not provide learning tools that support the teaching and learning process.

3. Factors that influence in applying the basic skills of teaching counselor of Balinese language at Banjar District Buleleng Regency is (1) factor of Educator (Councelorof Balinese language), Balinesecounselor less read reference and lack experience of counselor in implementing learning; (2) Factor learners, learners feel bored to follow the Balinese language lessons. (3) Learning facilities, schools do not have the cost to buy facilities that support learning.

4. The plan of solution implementation that can be proposed in basic component skills of Balinese language counselor in Banjar District, among others: first, varythe use of skill types that exist in strengthening skill; second, to open the learning first with apperception to direct the students before the learning is done, and before closing the lesson must do feedback on the lesson that has been going on; third, to make a good question in accordance with the level of difficulty so that students are not allowed to answer simultaneously; fourth, to give responsiveness and admonish the students so as not to fuss in the classroom and all learners to be noticed so there is no commotion; fifth, the Balinese language counselor in addition to varying his teaching style must also vary the interaction patterns and tools.

\section{Suggestion}

Based on the above conclusions, suggestions that can be submitted in this study are as follows.

1. Balinese Language Counselors should continue and need not hesitate to implement basic teaching skills in learning especially its components to encourage students to realize and use their understanding to develop themselves and solve problems faced in everyday life because basic teaching skills are essential for all situations learn.

2. For other teachers, this research can be used as a description or teacher guidance in implementing the learning process that leads to the application of basic teaching skills in learning.

3. For prospective researchers, this research can be used as an alternative to conduct research, because this research is limited to descriptive research only. For that, for prospective researchers can do research with this type of research. Classroom Action Research (CAR) to solve the problem of basic teaching skills to improve the quality of learning in school.

\section{References}

Budiasa, I. N. 2013. Pilihan Bahasa Oleh Kaum Remaja Di Daerah Tujuan Wisata Kuta, Bali, Kandai, 9(2), pp. 314-325.

Hasibuan. 1991. Proses Belajar Mengajar Keterampilan Dasar Pengajaran Mikro. Bandung: Remaja Rosdakarya. 